\title{
THE ROLE OF ANTIAPOPTOTIC ERYTHROPOIETIN ON ULTRAVIOLET B-INDUCED PHOTODAMAGED SKIN THROUGH INHIBITION OF SUNBURN CELLS
}

\author{
Handi Suyono $^{1}$, Kristian Sanjaya ${ }^{2}$, Deby Susanti ${ }^{3}$ \\ ${ }^{1}$ Department of Physiology, Faculty of Medicine, Widya Mandala Surabaya Catholic University, Surabaya, \\ ${ }^{2}$ Benning Clinic, Solo, ${ }^{3}$ Eternelle Clinic, Surabaya, Indonesia
}

\begin{abstract}
Ultraviolet light causes photodamaged skin leading to photoaging skin. Ultraviolet-B $(U V-B)$ causes epidermal keratinocyte apoptosis, namely sunburn cell, through apoptotic intrinsic pathway. Erythropoietin (EPO) has a role in cytoprotection in various tissues but its role to epidermal skin is not clear yet. This study was designed pretest-posttest control group design. Thirty two male mice Mus musculus, strain Balbc, were divided into control and treatment group, 16 mice each group. All mice were exposured by $U V-B$ light $16 \mathrm{~mJ} / \mathrm{cm} 2$, distance $30 \mathrm{~cm}$, duration 90 seconds, for 3 consecutive days. Four mice each group were randomly sacrificed as pretest data. The control mice were given aquadest subcutaneous injection $0.1 \mathrm{~mL}$, and treatment mice were given EPO subcutaneous injection $0.1 \mathrm{~mL}(100 \mathrm{IU} / \mathrm{kg} \mathrm{BW})$. UVB were given everyday with same protocol above. Treatments were given 4 times, interval 3 days. All mice were sacrificed to examine sunburn cells. Data were performed as mean \pm SD and analyzed by $t$-test using SPSS 17.0 with significant value $p<0.05$. Sunburn cells of pretest control were $25.00 \pm$ $4.85 \%$ and treatment group were $24.83 \pm 5.15 \%$. Sunburn cells significantly decreased $(p=0.002)$ in treatment group $(31.5 \pm$ $9.39 \%)$ than control $(50.83 \pm 6.70 \%)$. UV-B causes sunburn cells formation. EPO inhibits apoptosis through increasing NO production and eNOS expression, inhibiting caspase and proinflammatory cytokines, and increasing antiapoptotic protein. EPO has a role in skin apoptosis inhibition which is shown by decreased sunburn cells.
\end{abstract}

Keywords: Ultraviolet B; erythropoietin; sunburn cell; photodamaged skin; keratinocyte

\section{ABSTRAK}

Sinar ultraviolet mengakibatkan photodamaged skin sehingga memicu photoaging skin. Ultraviolet-B (UV-B) mengakibatkan apoptosis keratinosit epidermis, yaitu sunburn cell, melalui jalur intrinsic apoptosis. Erythropoietin (EPO) mempunyai peran sitoproteksi pada berbagai jaringan tetapi perannya pada epidermis kulit masih belum jelas. Rancangan studi ini adalah pretest-posttest control group design. Tiga puluh dua mencit jantan Mus musculus, galur Balbc, dibagi dalam kelompok control dan perlakuan, dengan 16 mencit per kelompok. Semua mencit dipapar sinar UV-B 16mJ/cm2, jarak $30 \mathrm{~cm}$, durasi 90 detik, selama 3 hari berturut-turut. Empat mencit per kelompok secara acak dikorbankan sebagai data pretest. Mencit control diberi injeksi subkutan aquadest 0,1 mL, dan mencit perlakuan diberi injeksi subkutan EPO 0,1 mL (100 IU/kg BB). UVB diberikan setiap hari sesuai protocol di atas. Perlakuan diberikan 4 kali, interval 3 hari. Semua mencit dikorbankan untuk pemeriksaan sunburn cell. Data disajikan dalam rerata \pm SB dan dianalisis uji t menggunakan SPSS 17.0 dengan nilai signifikan $p<0.05$. Pretest sunburn cell kontrol adalah 25,00 $\pm 4,85 \%$ dan kelompok perlakuan adalah $24.83 \pm 5.15 \%$. Sunburn cell berkurang signifikan $(p=0,002)$ pada kelompok perlakuan $(31,5 \pm 9,39 \%)$ dibandingkan control $(50,83 \pm 6,70 \%)$. UV-B mengakibatkan pembentukan sunburn cell. EPO menghambat apoptosis melalui peningkatan produksi NO dan ekspresi eNOS, penghambatan caspase dan sitokin proinflamasi, dan peningkatan protein antiapoptosis. EPO mempunyai peran dalam penghambatan apoptosis kulit yang ditunjukkan dengan pengurangan sunburn cell.

Kata kunci: Ultraviolet B; erythropoietin; sunburn cell; photodamaged skin; keratinosit

Correspondence: Handi Suyono, Department of Physiology, Faculty of Medicine, Widya Mandala Surabaya Catholic University, Pakuwon City campus, JL. Kalisari Selatan 1, Surabaya 60112. Phone: +6231-99005299. Fax: +6231-99005277. E -mail: handi@ukwms.ac.id

pISSN:2355-8393 • eISSN: 2599-056x • doi: http://dx.doi.org/10.20473/fmi.v56i2.21229

- Fol Med Indones. 2020;56:114-117 • Received 20 Apr $2018 \bullet$ Accepted 18 Oct 2018

- Open access under CC-BY-NC-SA license • Available at https://e-journal.unair.ac.id/FMI/

\section{INTRODUCTION}

Ultraviolet (UV) light causes photodamaged skin. UV light consists of UV-A, UV-B, and UV-C. UV-A promotes free radicals production, i.e., superoxide, hydroxyl radical, and hydrogen peroxide. Free radicals bind to DNA, protein, and lipid then lead to deformation and dysfunction of cell. UV-B directly damages DNA. 
UV-B has stronger destructive effect than UV-A. UV-C can not penetrate earth surface although the destructive effect is more stronger than UV-A and UV-B (Dr?ge 2002). Skin is organ that frequently exposed by UV light. UV-induced photodamaged skin can lead to photoaging skin or neoplasm.

UV exposure causes keratinocyte and Langerhan's cell apoptosis. Keratinocyte is the skin epidermal cell, and almost $90 \%$ found in epidermis. Keratinocyte serves as barrier by producing keratin and some protective proteins. Skin damage commonly manifest as inflammation, apoptosis (programmed cell death) and mutation (Pradhan et al 2008). Apoptotic keratinocyte is mentioned as sunburn cell. It can be seen in hematoxylin-eosin (HE) histological staining by light microscope. Sunburn cell is manifested as cell with condensated nucleus and eosinophilic cytoplasm (Raj et al 2006). UV-B induces sunburn cell formation through activation of proapoptotic caspase-3. In long term effect, UV-B promotes genes mutation and carcinogenesis via p53 gene mutation (Rigel et al 2004).

Recent studies report the role of growth factors in order inhibiting skin damage (Raj et al 2006). Erythropoietin (EPO) is a glycoprotein hormone which induce erythropoiesis by stimulating proliferation and differentiation of erythroid progenitor cells to be erthrocytes. EPO is classified as growth factor. EPO has non-erythropoietic effects to inhibit tissue damage by inhibiting apoptosis. Recent studies found the non-erythropoietic EPO function on cardiovascular, nervous, and kidney. EPO has 2 protective mechanism, direct and indirect. Direct mechanism occurs through anti-apoptosis, antioxidative, and anti-inflammatory against hypoxia or anoxia. Indirect mechanism occurs through angiogenic effect in order to improve oxygenation (Paschos et al 2008).

EPO increases nitric oxide (NO) production and endothelial nitric oxide synthase (eNOS) expression. The antiapoptotic effects of NO are reducing oxidative stress through inhibition of NADPH oxidase, modulation of HSP-70 and $\mathrm{Bcl}-2$ as protective genes, inhibition of caspase- 3 and -8 via S-nitrosylation (Burger et al 2006). Study by Sharples et al (2004) found that EPO prevented activation of caspase-3, -8, -9 and decreased apoptotic cells. EPO decreased DNA fragmentation and caspase-3 via increasing antiapoptotic protein Bcl-XL and XIAP (Sharples et al 2004).

Several studies found the effect of EPO on skin. EPO enhanced wound healing of diabetic mice. EPO promotes angiogenesis via induction of VEGF and proliferation of vascular endothelium. EPO improved wound healing by improving tissue oxygenation
(Galeano et al 2004). EPO enhanced granulation tissue formation. Complex EPO and EPO-receptor associated with inducible NOS (iNOS) level in granulation tissues. EPO improved skin through NO mechanism (Haroon et al 2003). This study aimed to find the effect of EPO to reduce sunburn cells. EPO is expected as a choice of skin medication especially photodamaged skin.

\section{MATERIALS AND METHODS}

This study used pretest-posttest control group design. The study was done in Biochemistry Lab, Faculty of Medicine, Universitas Airlangga, Surabaya, after approved by Ethical Committee of Faculty of Medicine, Widya Mandala Surabaya Catholic University. Thirty two male mice Mus musculus, strain Balbc, 25 gram, age 4 months, were randomly divided into control and treatment group, 16 mice each group. All mice were exposured by UV-B lamp (Snakyo Denki®), 280-360 $\mathrm{nm}$, peak $306 \mathrm{~nm}$ ), $16 \mathrm{~mJ} / \mathrm{cm} 2$, distance $30 \mathrm{~cm}$, duration 90 seconds, in 3 consecutive days. Four mice of each group were randomly selected to sacrifice by eter anesthesia and examined in HE histological staining as pretest data. Sunburn cells were examined by light microscope 400x magnification. Skin sample was collected from back with size $20 \mathrm{~mm}$ x $10 \mathrm{~mm}$. Control mice were injected subcutaneous aquadest $0.1 \mathrm{~mL}$, and treatment group subcutaneous EPO (Hemapo®, Kalbe Farma) $0.1 \mathrm{~mL}$ (100 IU/kg BW). Injections were given 4 times, interval 3 days. The protocol was finished for 12 days. All mice were sacrificed by the same procedure above. Data were performed as mean \pm SD and analyzed by t-test using SPSS 17.0 for Windows with significant value $\mathrm{p}<0.05$.

\section{RESULTS}

Table 1. Sunburn cell data

\begin{tabular}{lll}
\hline Groups & Pretest & Posttest \\
\hline Control & $25.00 \pm 4.85 \%$ & $50.83 \pm 6.70 \%$ \\
Treatment & $24.83 \pm 5.15 \%$ & $31.5 \pm 9.39 \%$ \\
\hline
\end{tabular}

Data distribution were normal (Shapiro-Wilk test). Sunburn cells pretest of treatment group were not significant compared to control $(\mathrm{p}=0.955)$. Sunburn cells posttest of treatment group were significant compared to control $(\mathrm{p}=0.002)$. Sunburn cells of control group significantly increased $(p=0,001)$ at the end of study but the treatment group unsignificantly increased $(\mathrm{p}=0.189)$. 


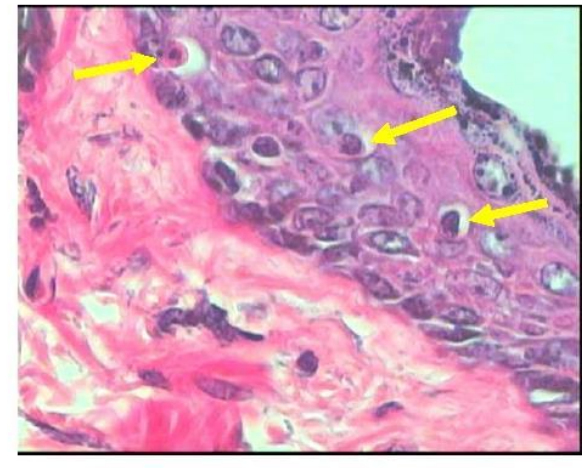

Fig. 1. Sunburn cells of pretest control group (magnified 400x).

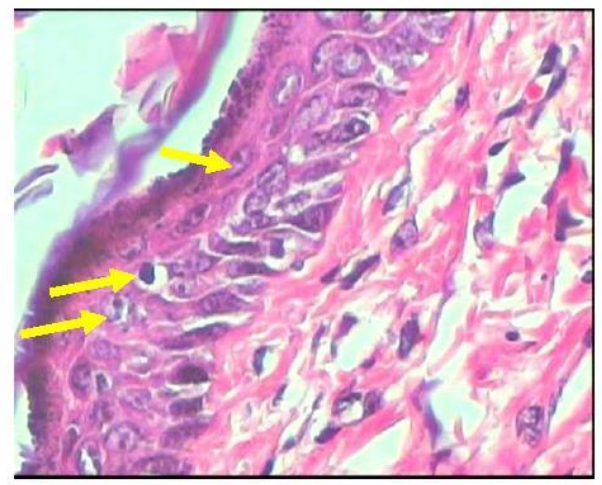

Fig. 2. Sunburn cells of pretest treatment group (magnified 400x).

\section{DISCUSSION}

UV-B causes direct damage to keratinocyte's DNA. UV-B promotes thymine dimer formation. UV-B activates intrinsic pathway of apoptosis. Caspase- 3 is activated then lead to chromatin condensation and nucleus fragmentation (Elanore 2007). UV-B promotes multimerization Fas death receptors leading to caspase8activation and Bid lysis. Membrane-based signaling and DNA damage involve in UV-induced keratinocyte apoptosis. UV-B exposures manifest as skin lesion, e.g. erythema, dry skin (Raj et al 2006).

Control mice had dry skin and erythema after UV-B exposures. Two mice died on the 12th day. The possible causes of death were diffuse skin damage and systemic effects of UV-B. UV-B increases proinflammatory mediators, namely prostaglandin E2, IL-1, IL-6, TNF-a. Systemic inflammation lead multiple organ dysfunction (Boonstra et al 2000).

Treatment mice had minimal dry skin and erythema. All mice lived until the end of study. EPO is glycoprotein hormone, $30.4 \mathrm{kDa}$, produced as response to hypoxia or anoxia. EPO has functions as autocrine, paracrine, and endocrine. EPO is mainly produced, almost $90 \%$, in kidneys by peritubular interstitial cells (type II fibroblast, near proximal tubule base inside renal cortex and outer renal medulla). EPO can be produced extrarenal, approximately $10 \%$, especially in liver by hepatocytes and Kupferr cells, in brain by astrocytes (Faundrey 2004).

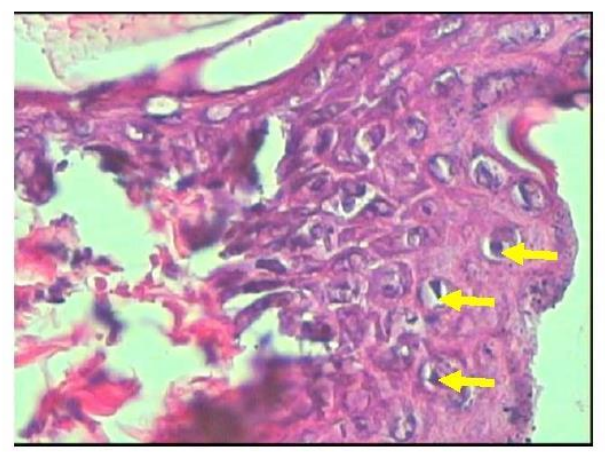

Fig. 3. Sunburn cells of posttest control group (magnified 400x).

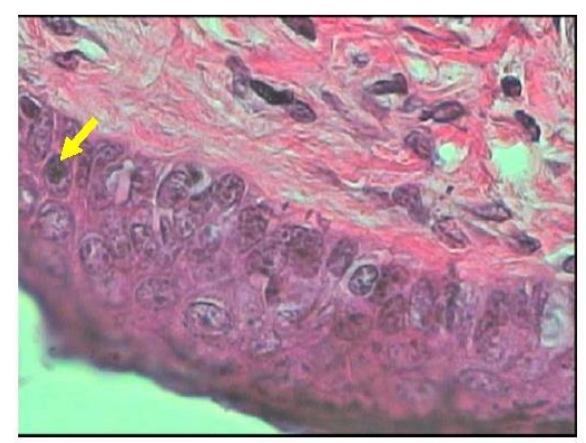

Fig. 4. Sunburn cells of posttest treatment group (magnified 400x).

Primary function of EPO is erythropoiesis. EPO stimulates proliferation and differentiation of erythroid progenitor cells to be erythrocytes. mRNA EPO increases maximum 4-8 hours after hypoxic stimulus (Faundrey 2004). EPO receptors have been found in kidney, brain, retina, heart, lungs, skin, smooth muscle, and testis (Lapin 2003). EPO has a renoprotective role especially inhibiting acute kidney ischemia. EPO has a cardioprotective role to reduce infarct size and promote angiogenesis in heart ischemia. EPO has a neuroprotective role in central and peripheral nervous system (Schirer 2007). 
Previous studies report EPO as antiapoptosis. EPO inhibited myocard apoptosis via NO and eNOS (Burger et al 2006). EPO inhibited peritoneal mesothelium apoptosis via inhibition of caspase-3 and DNA fragmentation (Vorobiov et al 2008). EPO inhibited human alveolar and bronchial epithelium apoptosis in vitro. EPO induced angiogenesis and inhibited apoptosis of leg skeletal muscle ischemia (Joshi et al 2010). EPO could inhibit oxidative damage and proinflammatory cytokines. EPO had been found inhibited IL-1B, IL-6, TNF-a, TGF-ß1 (Li et al 2006).

EPO binds to EPO-receptor in the skin. This complex activates Jak2 phosphorilation. Jak2 activates STAT. STAT moves to nucleus to promote genes transcription which aim to protect cell and inhibit apoptosis (Smith et al 2003, Maiese et al 2008). EPO also attenuates apoptosis through antiapoptotic protein Bcl-XL increase (Hamed et al 2010). There are various mechanisms of antiapoptotic EPO. We need further investigations especially on pathological skin.

Our study found the effect of antiapoptotic EPO on skin by decreasing sunburn cells. We still need further studies on other properties of skin, e.g. dermis, extracellular matrix, other skin cells, and the exact mechanism of antiapoptotic EPO. EPO can increase erythrocytes, platelets, $\mathrm{PCV}, \mathrm{Hb}$, and mean arterial pressure (MAP). EPO causes thrombosis or thromboemboli, increase blood viscosity, hypertension (Smith et al 2003). The side effects of EPO should be considered if we want to apply in clinical case. In our study, we did not investigate these side effects. EPO is expected to be a choice medication to prevent or improve pathological skin.

\section{CONCLUSION}

UV-B causes epidermal keratinocyte apoptosis which manifest as sunburn cell. UV-B promotes photodamaged skin. EPO has an antiapoptotic function to ameliorate UV-B-induced photodamaged skin. EPO decreases sunburn cells.

\section{ACKNOWLEDGMENT}

We declare no conflict of interest in this study. The study was funded by Faculty of Medicine, Widya Mandala Surabaya Catholic University.

\section{REFERENCES}

Boonstra A, van Oudenaren A, Barendregt B, et al (2000). UVB irradiation modulates systemic immune responses by affecting cytokine production of antigenpresenting cells. International Immunology 12, 15311538

Burger D, Lei M, Morphet NG, et al (2006). Erythropoietin protects cardiomyocytes from apoptosis via up-regulation of endothelial nitric oxide synthase. Cardiovascular Research 72, 51-59

Galeano M, Altavilla D, Cucinotta D, et al (2004). Recombinant human erythropoietin stimulates angiogenesis and wound healing in the genetically diabetic mouse. Diabetes 53, 2509-2517

Hamed S, Ullmann Y, Masoud M, et al (2010). Topical erythropoietin promotes wound repair in diabetic rats. Journal of Investigative Dermatology 130, 287-294

Haroon Z.A, Amin K, Jiang X, et al (2003). A novel role for erythropoietin during fibrin-induced woundhealing response. Am J Pathol 163, 993-1000

Joshi D, Tsui J, Ho TK, et al (2010). Review of the role erythropoietin in critical leg ischemia. Angiology 61, 541-550

Lapin T (2003). The cellular biology of erythropoietin receptors. The Oncologist 8, 15-18

Li Y, Takemura G, Okada H, et al (2006). Reduction of inflammatory cytokine expression and oxidative damage by erythropoietin in chronic heart failure. Cardiovascular Research 71, 684-694

Maiese K, Chong Z. Z, Hou J, et al (2008). Erythropoietin and oxidative stress. Curr Neurovasc Res 5, 125-142

Paschos N, Lykissas M.G, Beris AE (2008). The role of erythropoietin as an inhibitor of tissue ischemia. Int $\mathbf{J}$ Biol Sci 4, 161-165

Pradhan S, Kim HK, Thrash CJ, et al (2008). A critical role for proapoptotic protein bid in ultraviolet-induced immune suppression and cutaneous apoptosis. J Immunol 181, 3077-3088

Raj D, Brash D.E, Grossman D (2006). Keratinocyte apoptosis in epidermal development and disease. J Invest Dermatol 126, 243-257

Rigel DS, Weiss RA, Lim HW, et al (2004). Photoaging. Canada, Marcel Dekker Inc., p 34

Sharples EJ, Patel N, Brown P, et al (2004). Erythropoietin protects the kidney against the injury and dysfunction caused by ischemia-reperfusion. J Am Soc Nephrol 15, 2115-2124

Smith K. J, Bleyer AJ, Little WC, et al (2003). The cardiovascular effects of erythropoietin. Cardiovascular Research 59, 538-548

Vorobiov M, Malki M, Schnaider A, et al (2008). Erythropoietin Prevents Dyalisis Fluid-Induced Apoptosis of Mesothelial Cells. Perit Dial Int, 28(6), 648-654 